\title{
Warming of Atlantic Water in three west Spitsbergen fjords: recent patterns and century-long trends
}

\author{
Ekaterina V. Bloshkina, ${ }^{1}$ Alexey K. Pavlov ${ }^{2,3}$ \& Kirill Filchuk ${ }^{1}$ \\ ${ }^{1}$ Arctic and Antarctic Research Institute, St. Petersburg, Russia \\ ${ }^{2}$ Institute of Oceanology, Polish Academy of Sciences, Sopot, Poland \\ ${ }^{3}$ Akvaplan-niva, Troms $\varnothing$, Norway
}

\begin{abstract}
We investigated the recent warming of summer Atlantic Water in relation to the century-long trends in maximum temperature in three west Spitsbergen fjords: Isfjorden, Grønfjorden and Billefjorden. On the basis of repeated alongfjord transects in late summer 2003-2019, we found that the warming has been pronounced not only in the outer but also in the inner domain of Isfjorden, where the presence of waters of Atlantic origin was registered more frequently after 2011 compared to early 2000s. Furthermore, Atlantic waters occurred more frequently in the bottom layers in the inner part of the fjord. In all the investigated fjords, the year 2014 was the warmest and saltiest during the period 2003-2019, which is consistent with previous reports for other west Spitsbergen fjords. In 2014 , the mean temperature and salinity in Isfjorden and Grønfjorden exceeded $4.9^{\circ} \mathrm{C}$ and 34.7 (in Billefjorden, $4.0^{\circ} \mathrm{C}$ and 34.67 , respectively). With the new data for 2010-19, we extended the time-series of maximum Atlantic Water temperature in Isfjorden and Grønfjorden, covering 1912-2009, reported previously by Pavlov et al. 2013. For the period 19122019, the average long-term trend of Atlantic Water maximum temperature is $0.25^{\circ} \mathrm{C} /$ decade and $0.22^{\circ} \mathrm{C} /$ decade in the outer part of Isfjorden and Grønfjorden, respectively. In the first two decades of the 21 st century, the warming trend is steeper compared to the 20 th century, $0.78{ }^{\circ} \mathrm{C} /$ decade in Isfjorden and $0.56{ }^{\circ} \mathrm{C} /$ decade in Grønfjorden, highlighting the strength of the ongoing 'Atlantification' of west Spitsbergen fjords.
\end{abstract}

\section{Keywords}

Atlantification; Svalbard; Isfjorden; Grønfjorden; water masses; climate change

\section{Correspondence}

Ekaterina V. Bloshkina, Arctic and Antarctic Research Institute, Beringa St. 38, 199397 St. Petersburg, Russia. E-mail: bloshkinaev@mail.ru

\section{Abbreviations}

AARI: Arctic and Antarctic Research Institute, Russia

ArW: Arctic Water

AW: Atlantic Water

LW: Local Water

RAE-S: Russian Scientific Arctic Expedition on Spitsbergen Archipelago

TAW: Transformed Atlantic Water WCW: Winter Cooled Water WSC: West Spitsbergen Current

\section{Introduction}

The first descriptions of water masses in west Spitsbergen fjords were provided in pioneering studies by HellandHansen and Nansen more than a century ago (HellandHansen \& Nansen 1912; Nansen 1915). In the past two decades, several studies have shown that the water mass variability in west Spitsbergen fjords is driven by the interaction of several processes: advection of warm and salty AW and fresher and colder ArW, their subsequent mixing resulting in the formation of TAW, freshwater input from land, precipitation, and the formation of LW and WCW through sea-ice formation and winter convection (Saloranta \& Svendsen 2001; Svendsen et al. 2002; Cottier et al. 2005; Nilsen et al. 2008). The AW, the region's primary heat source, originates from the WSC, a northward extension of the North Atlantic Current. The WSC brings the biggest volume of AW into the Arctic Basin (Schauer et al. 2008) and is responsible for the largest heat transport towards the central Arctic Ocean (Aagaard $\&$
Carmack 1989; Boyd \& D'Asaro 1994; Rudels et al. 2015; Kolås \& Fer 2018). Originating from the East Spitsbergen Current, ArW is transported northward over the west Spitsbergen shelf (Bischof 2000; Haarpaintner et al. 2001), often separating west Spitsbergen fjords from the direct influence of AW from the WSC. Within an annual cycle, the waters on the shelf and in the adjacent fjords typically switch from a state of Arctic dominance (cold and less saline water in winter) to a state of Atlantic dominance (warm and saline water in summer) and back (Svendsen et al. 2002; Cottier et al. 2005; Nilsen et al. 2008).

However, since the early 2000s, evidence of substantial AW advection into the shelf and fjords also in winter has been documented (Cottier et al. 2007; Nilsen et al. 2008). Consequently, there have been reports of increasing AW temperature in west Spitsbergen fjords in the early 2000s (Pavlov et al. 2013; Tverberg et al. 2019; Skogseth et al. 2020). An increased influence of the AW inflow in west Spitsbergen fjords and the European sector 
of the Arctic Ocean is often referred to as 'Atlantification' (Årthun et al. 2012; Polyakov et al. 2017). It is manifested as the increase in the share and volume of AW of the water column, accompanied by elevated water temperature and salinity in the Arctic Ocean (Asbjørnsen et al. 2020; Polyakov et al. 2020). Furthermore, it may imply a shoaling of the AW layer, altered stratification, enhanced vertical mixing and loss of sea ice (Zhuravskiy et al. 2012; Polyakov et al. 2017; Asbjørnsen et al. 2020). The changes in the physical environment have important regional implications, from increasing melting rates of glaciers (Luckman et al. 2015; Holmes et al. 2019) to profound changes in the structure and functioning of local fjord ecosystems (Berge et al. 2005; Berge et al. 2015; Łącka \& Zajączkowski 2016; Vihtakari et al. 2018; Hop et al. 2019; Payne \& Roesler 2019; Mańko et al. 2020). In this study, the term 'Atlantification' is related to describing the spatial and temporal variabilities and patterns of the AW warming in different parts of Isfjorden, Grønfjorden and Billefjorden.

Svalbard is one of the most studied regions in the Arctic. Investigations of the physical, ecological and biogeochemical aspects of the marine systems of west Spitsbergen fjords often require multiyear time series characterizing oceanographic conditions. Despite the interest from the research community, there have so far been a limited number of systematic and detailed descriptions of the longterm variability in the Isfjorden system. Among those, a study by Pavlov et al. (2013) investigated the long-term trends of AW during 1912-2009, and the latest work by Skogseth et al. (2020) analysed the variability of the mean summer (July-September) temperature and salinity in the top $250 \mathrm{~m}$ in Isfjorden over the past 30 years.

In this study, we look at patterns of variability of the AW temperature and salinity during 2003-2016 in the inner and outer parts of Isfjorden, Grønfjorden and Billefjorden. Furthermore, by extending the time-series of maximum AW temperature in Isfjorden and Grønfjorden during 1912-2009 (initially reported by Pavlov et al. 2013), we have constructed the longest available to date record of AW in west Spitsbergen fjords, helping to reveal the ongoing patterns of 'Atlantification' in the area since the early 2000 s.

\section{Area of study}

Isfjorden is one of the largest fjords in the Svalbard archipelago (Fig. 1), about $100 \mathrm{~km}$ long and $20 \mathrm{~km}$ wide across its central part, stretching from the south-west to the north-east. Waters from the adjacent continental shelf can freely penetrate the fjord because there is no sill at its entrance. However, free water exchange between
Isfjorden and the adjacent shelf is often regulated by the density gradient between fjord water masses and Atlanticorigin shelf waters (Nilsen et al. 2008; Skogseth et al. 2020). Billefjorden is a smaller fjord inside Isfjorden, about $30 \mathrm{~km}$ long and $5-8 \mathrm{~km}$ wide. It is the only fjord in the Isfjorden system with two topographic barriers at the entrance. The outer sill is $70 \mathrm{~m}$ deep (Fig. 1). The inner sill is approximately $50 \mathrm{~m}$ deep (Fig. 1; Nilsen et al. 2008). These topographic barriers prevent substantial water exchange with neighbouring parts of Isfjorden. Grønfjorden is a relatively small fjord located on the south side of Isfjorden, near its mouth. Its length is approximately $16 \mathrm{~km}$, and its width ranges $2-5.5 \mathrm{~km}$. The absence of a sill allows for a relatively free water exchange with the adjacent part of Isfjorden.

\section{Data and methods}

We use two sources of oceanographic data (temperature, salinity and pressure) in this work: the in situ observations carried out by AARI and data from the World Ocean Database (Boyer et al. 2018). The data used in the article are restricted to the summer months of August-October during the period 2003-2019 in Isfjorden and Billefjorden, and 2010-19 in Grønfjorden (Fig. 1).

In the first part of the study, we use in situ temperature and practical salinity data collected during annual surveys at one along-fjord and three cross-fjord sections in Isfjorden between 2003 and 2016 (stations il-i34), one along-fjord and one cross-fjord section in Grønfjorden between 2010 and 2019 (stations gl-g10) and one alongfjord section in Billefjorden between 2003 and 2015 (stations i35-i37). The stations of the along-fjord section in Isfjorden ( 11 stations in total) are located along the south side of the fjord. The along-fjord sections in Grønfjorden (eight stations in total) and Billefjorden (three stations in total) are aligned along the central axes of the fjords.

The shallowest stations with depths not exceeding 100-150 m (i19-i20, i23 and i34) are located mainly on the sides of the inner part of Isfjorden. The deepest stations with bottom depths of 370-400 m (i4-i5) are located at the Isfjorden entrance. The remaining stations have a depth of 150-200 m (i8, i18, i22, i24-i28 and i31-i33), 200-250 m (i1, i9-il7 and i29-i30) and 250-300 $\mathrm{m} \mathrm{(i2-i3,} \mathrm{i6-i7} \mathrm{and}$ i21). In Grønfjorden, the stations g8-g10 are 50-100 m deep, and the remaining ones are 100-160 m deep (gl-g7).

Vertical profiles of in situ temperature and practical salinity during AARI campaigns were recorded using factory-calibrated RBR Concerto $6 \mathrm{~Hz}$ (RBR Inc.) and SBE-19 conductivity-temperature-depth sensors (SeaBird Electronics). Both sensors were routinely calibrated following the recommendations from the manufacturers. 

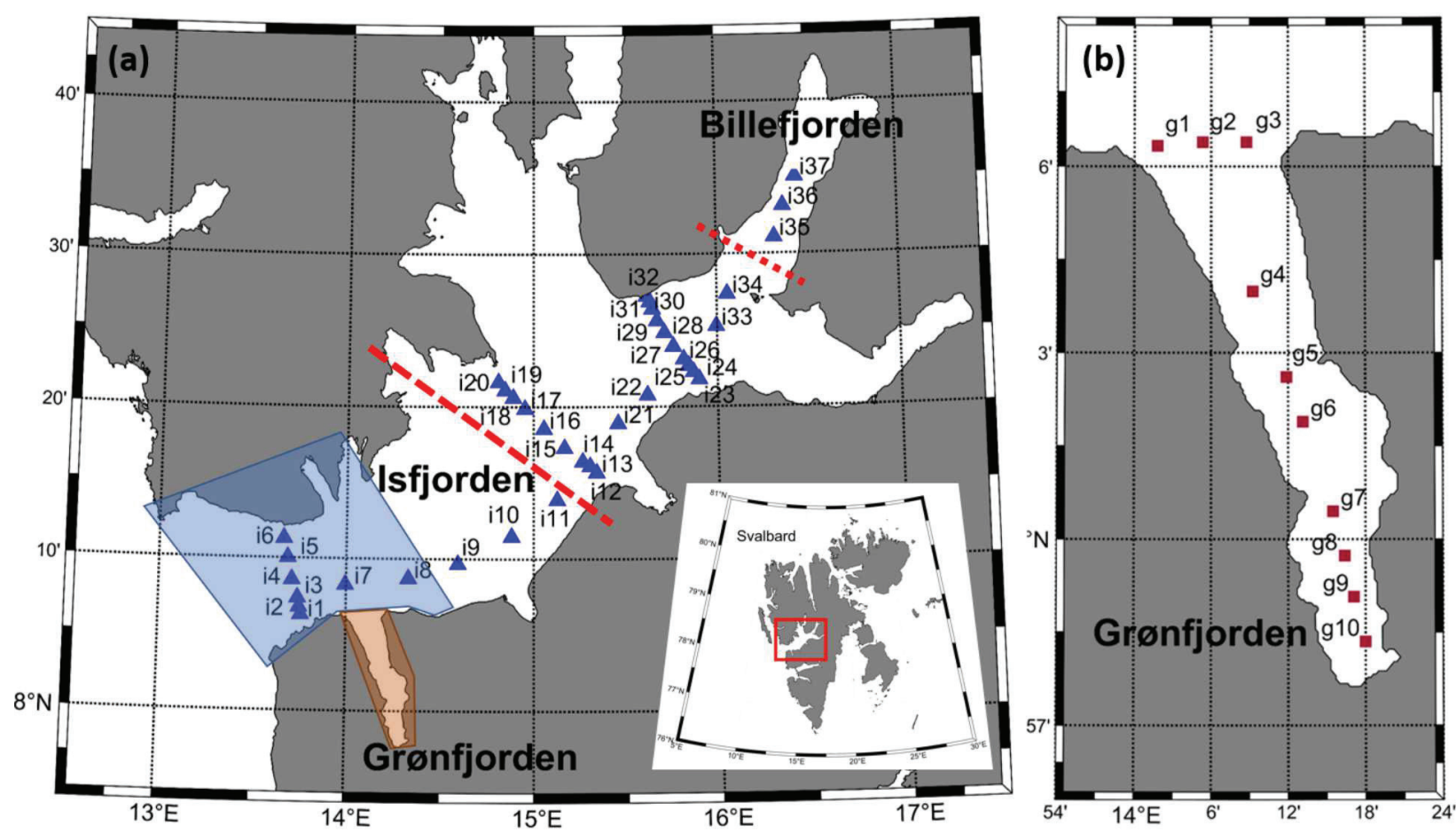

Fig. 1 (a) Station map of Isfjorden and Billefjorden, with an inset map of Svalbard. Triangles show stations of the repeated sections sampled in $2003-2016$. Semi-transparent blue and red polygons depict domains used in the study by Pavlov et al. (2013). All observations collected between 2010 and 2019 in these domains were used to extend the time series of AW maximum temperature from Pavlov et al. (2013) to 1912-2019. The dashed line divides Isfjorden into outer and inner domains. The red dotted line separates the three stations routinely sampled in Billefjorden and approximately corresponds to the sill (another sill is located between station 35 and i36). (b) Station map of Grønfjorden.

The basic data processing was done using the software provided by the manufacturers. The data were binned with a vertical resolution of $1 \mathrm{~m}$, and the data in the top $3 \mathrm{~m}$ were excluded from the analysis.

This study focuses on patterns of the AW variability in the fjords. For convenience, we use a broader definition of AW in this paper, which includes waters with an in situ temperature (T) of $>1{ }^{\circ} \mathrm{C}$ and a practical salinity (S) of $>34.7$ and the ranges that cover both AW and TAW domains in earlier classifications for this region by Cottier et al. (2005) and Nilsen et al. (2008). We will refer to this definition as AW/TAW throughout the text. For the analysis, we calculated a percentage of the water column that AW/TAW occupied on each vertical profile of $\mathrm{T}$ and $\mathrm{S}$ in our data set.

For the analysis of the century-long time-series of maximum AW/TAW, we used a similar procedure and domains in Isfjorden and Grønfjorden (Fig. 1) as in Pavlov et al. (2013). In brief, Pavlov et al. (2013) used several different data sources: the International Council for the Exploration of the Sea oceanographic database, data collected by the World Data Centre (Obninsk, Russia), data collected by the Norwegian Polar Institute (Norway), AARI and the University Centre in Svalbard. In the study, a surface layer of $75 \mathrm{~m}$ for Isfjorden and $50 \mathrm{~m}$ for Grønfjorden was excluded from the analysis. For the long-term trend estimation, the maximum temperature in the AW layer was selected. The time-series of maximum temperature recorded in each year was constructed using data from 53 sampled years for Isfjorden and 27 sampled years for Grønfjorden.

\section{Results and discussion \\ Patterns of the AW variability in 2003-2019}

Between 2003 and 2016, several years were marked by the elevated presence of AW/TAW in Isfjorden: 2006, 2008, 2011, 2013, 2014 and 2016 (Fig. 2). In those years, the largest fractions of AW/TAW presence in the water column were recorded, with average values for Isfjorden of more than $30 \%$. Furthermore, in the inner part of the 
fjord, AW/TAW was observed at all stations except the shallowest ones near the shore (i.e., stations i23, il 9 and i20). During the period of consideration, the maximum presence of AW/TAW in the waters of the fjord was recorded in 2014, when AW/TAW occupied over $80 \%$ of the water column at all stations (Fig. 2). In 2014, AW/ TAW even penetrated Billefjorden, where AW/TAW occupied up to $20 \%$ of the water column, which is rather a unique case: our observations show that AW and TAW were rarely present in Billefjorden in 2011-19. Similar to Isfjorden, conditions in summer 2014 were also exceptional in Grønfjorden, where there was also an increased share of AW/TAW in the water column, reaching up to $50-70 \%$ in the northern (outer) part of the fjord (stations $\mathrm{gl}-\mathrm{g} 7$ ) and $7-18 \%$ in the southern (inner) part of the fjord (stations g8-g10; Fig. 2). For comparison, Kongsfjorden and Hornsund, the other two large fjords in west Spitsbergen, were also almost entirely filled with AW and TAW in the summer of 2014 (Promińska et al. 2017; Tverberg et al. 2019). Grønfjorden was also characterized by the presence of AW/TAW almost annually from 2011 to 2019, except for 2015 (Fig. 2).

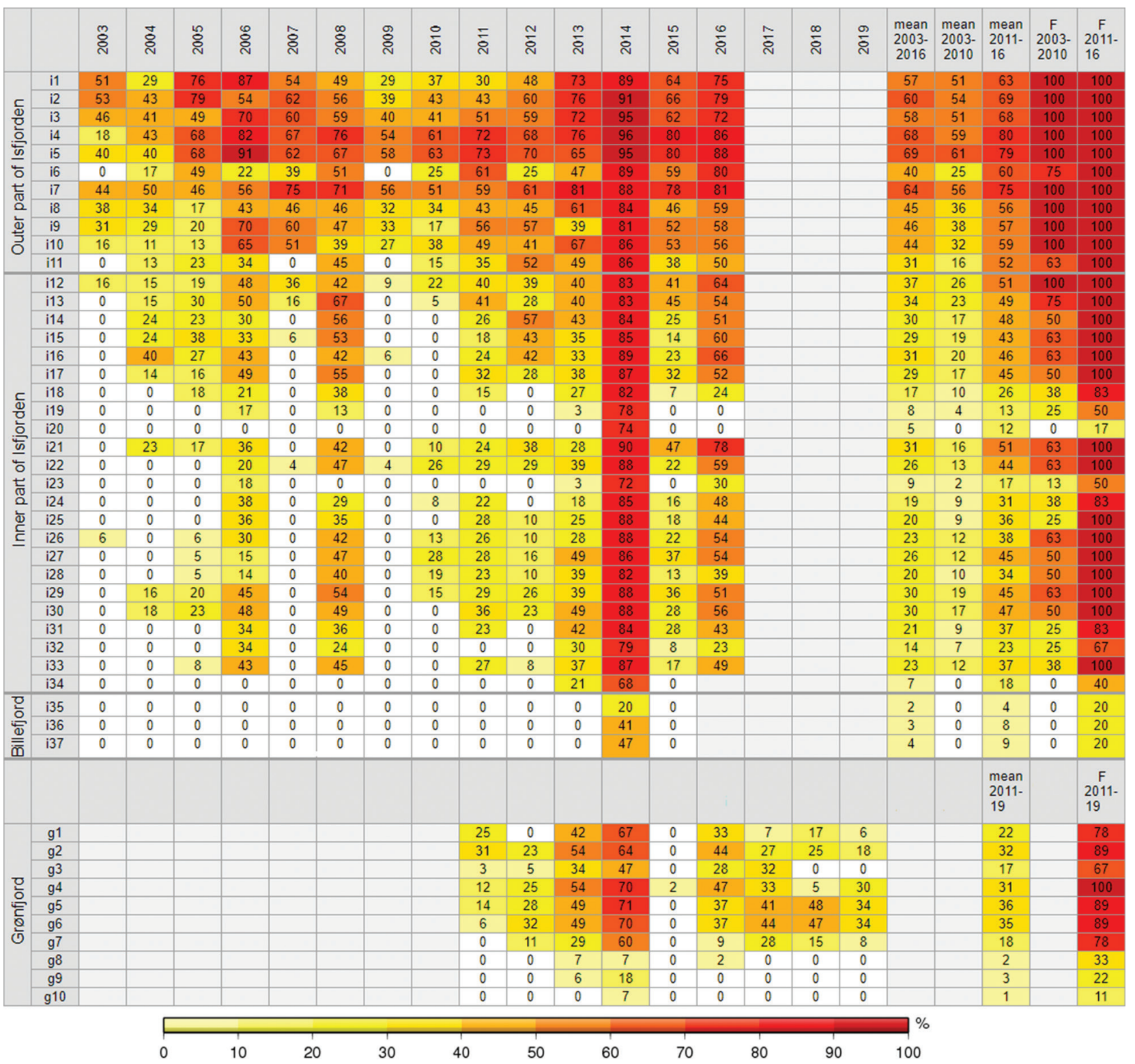

Fig. 2 Distribution of the proportion of AW/TAW (shown as percentage of the total water column) in Isfjorden (including Billefjorden) in August-October 2003-2016 and Grønfjorden in August-October 2011-19. 
For a more robust quantitative assessment of AW/TAW intrusions into different parts of Isfjorden in the past two decades, we calculated the parameter $\mathrm{F}$ for the two periods, 2003-2010 (eight years) and 2011-16 (six years), as a ratio between the number of years in which AW/TAW was recorded at a given station to the number of years in the respective time period and multiplied by 100 (Fig. 2). At the entrance of Isfjorden, F reached 100 for both periods, meaning that AW/TAW was present in all years (Fig. 2). In the inner part of Isfjorden, F was 100 almost at all stations in 2011-16, while in 2003-2010, it was often below 50. The obtained estimates of the average share of AW/TAW for two periods (Fig. 2) showed that the most remarkable changes in the presence of AW/TAW in the water column occurred in the inner part of Isfjorden. So, before 2011 , the occurrence of AW/TAW in the inner part of Isfjorden did not exceed $20 \%$, and in the following six years, it increased to $30-40 \%$. In the outer part of Isfjorden, an increase in the share of AW/TAW in the water column is also noticeable from $35-55 \%$ in the period $2003-2010$ up to $55-75 \%$ in the period 2011-16. In Grønfjorden, the average values of the share of AW/TAW during the study period 2011-19 were $20-30 \%$ at almost all stations, except for the innermost part of the fjord (g8-g10), where AW/TAW rarely penetrated. The absence of data in the early 2000s in our time series at stations il-i34 makes it difficult to conclude whether significant warming of Isfjorden took place before 2006. However, our results agree well with earlier reports of intensified AW/TAW advection into Kongsfjorden taking place since 2006 (Promińska et al. 2017; Tverberg et al. 2019), which suggests that the widespread 'Atlantification' of west Spitsbergen fjords has been taking place since after 2006. Furthermore, our time series provide evidence that a more persistent AW/TAW signal has been present in Isfjorden since 2011, indicating a transition to a warmer hydrographic state in summer.

Recent studies of hydrographic conditions in west Spitsbergen fjords (Tverberg et al. 2019; Skogseth et al. 2020) have linked the interannual variability in the AW/TAW content in summer months to processes and conditions that develop in the fjords during winter. Three different types of winter conditions have been suggested: 'Winter Deep,' 'Winter Intermediate' and 'Winter Open.' The 'Winter Deep' case was the most common until the recent warming of the fjords in the early 2000s, when deep convection, combined with the formation of sea ice, created dense winter water that prevented AW/TAW from penetrating deep into the fjords as long as the density gradient persisted between the shelf waters and the waters in the fjords. Following such winter conditions, the AW/TAW inflow was relatively small, and AW/TAW did not penetrate far into the fjord. Under 'Winter Intermediate' conditions, winter convection develops from the surface to intermediate depths. After such winters, AW/TAW penetrates the fjords in larger volumes, but only in the bottom layers. The maximum inflows of AW/TAW in the summer months are observed after the 'Winter Open' cases when sea ice does not form and only thermal convection is observed, which occur more often lately (Tverberg et al. 2019). For example, the winter of 2014, after which the maximum inflow of AW/TAW was recorded in Isfjorden (Fig. 2), belonged to the 'Winter Open' type (Skogseth et al. 2020). The winter of 2003, when AW/TAW was recorded only in the outer part of Isfjorden, was of the 'Winter Deep' type. In addition to internal mechanisms regulating the AW/TAW inflows into the fjords' interiors, there are also external factors (acting on the adjacent shelf and outer parts of the fjords). For example, previous works documented that more frequent AW advection from the shelf towards fjords is linked to specific regional atmospheric circulation patterns in wintertime (Cottier et al. 2007; Pavlov et al. 2013; Nilsen et al. 2016), which induce enhanced cross-shelf exchange via zonal Ekman transport of warm and salty AW from WSC towards the shelf and fjords (Goszczko et al. 2018).

We also looked more specifically at the frequency of AW/TAW occurrence in the bottom layer, defined in this study as a 15-m deep layer above the seafloor. The near-bottom characteristics have not been reported previously but could be of particular importance for, for example, benthic ecology studies. At the outer part of Isfjorden (stations il-i10), the bottom layer was occupied by AW/ TAW almost every summer since 2003. In the inner part of Isfjorden (stations i12-i34), prior to 2010, near-bottom AW/TAW was observed at a majority of the stations only in 2006 and 2008 (Fig. 3), while after 2010, AW/TAW in the bottom layer was recorded almost every year, especially at stations i22-i34. Grønfjorden is also characterized by the presence of AW/TAW in the bottom layer annually from 2011 to 2019 at stations gl-g7, with the exception of 2015.

\section{Temperature and salinity variability in fjords in 2003-2019}

To get a more quantitative understanding of AW/TAW variability in the study area in 2003-2019, we looked at the interannual variability of average August-October T and $S$ of the AW/TAW and in the whole water column in Isfjorden, Grønfjorden and Billefjorden, respectively (Fig. 4). In the case of Isfjorden, we divided it into two domains (Fig. 1)-outer (stations il-ill) and inner (stations i12-i34)-and calculated average $\mathrm{T}$ and $\mathrm{S}$ for each of them separately.

The pattern of interannual variability between average $\mathrm{T}$ and $\mathrm{S}$ values for AW/TAW and the whole water column is 


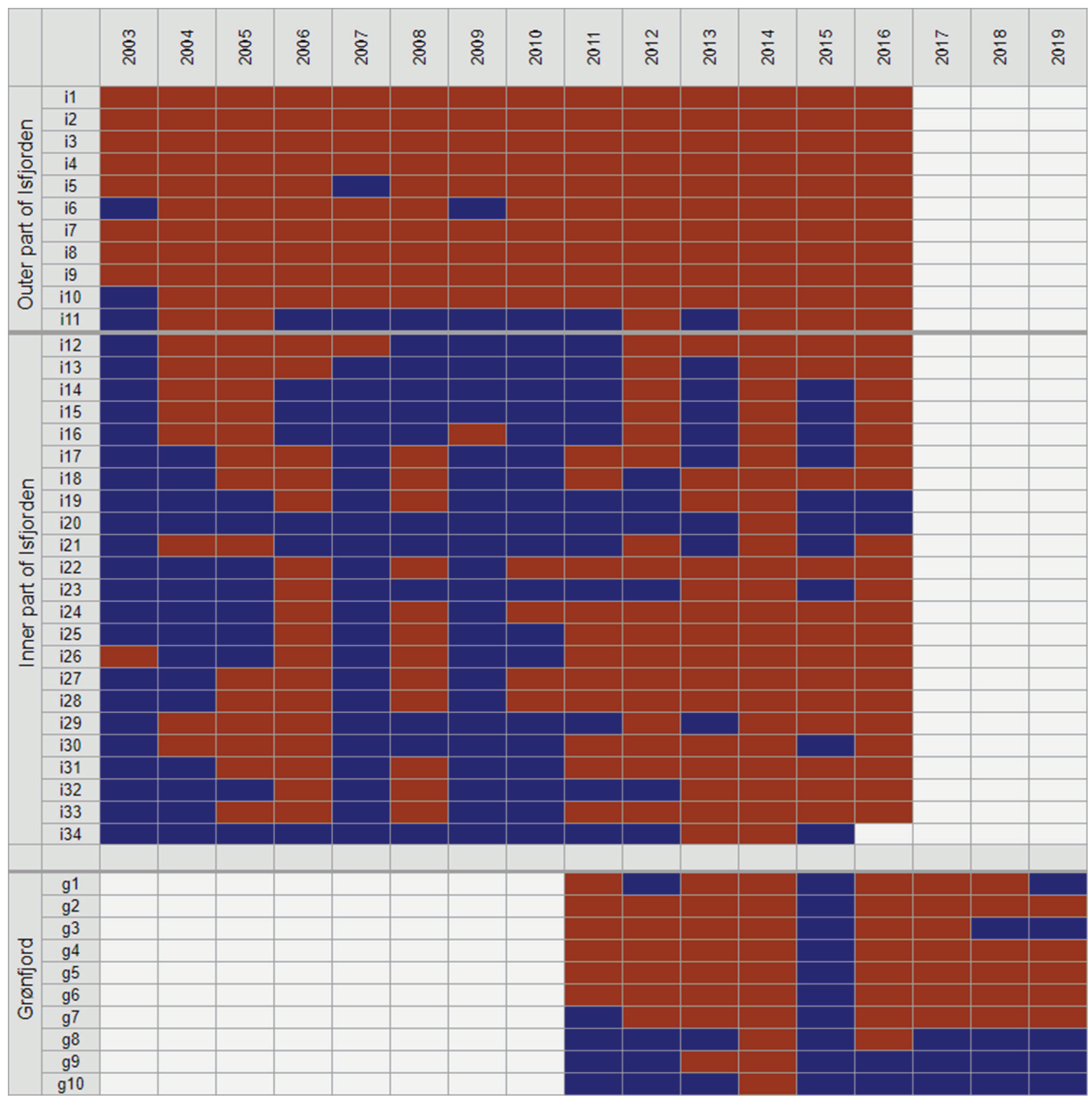

Fig. 3 The occurrence of AW/TAW in the bottom layer at all stations in Isfjorden, August-October 2003-2016, and Grønfjorden, August-October 2011-19. Red represents the presence of AW/TAW, and blue indicates that AWITAW was not present.

similar. The highest average $\mathrm{T}$ and $\mathrm{S}$ were observed in 2014-a year when Isfjorden and Grønfjorden were almost entirely filled with AW/TAW - in all three fjords, both in AW/ TAW and the entire water column (Fig. 2). The year 2014 was also the only year when AW/TAW was detected in Billefjorden (Fig. 4a). In the outer domain of Isfjorden, average AW/TAW temperature above $3{ }^{\circ} \mathrm{C}$ and salinity higher than 34.89 were observed in 2006-08 and consistently every year since 2013. Maximum values were found in 2014 , reaching up to $4.68^{\circ} \mathrm{C}$ and 35.05, respectively. The year 2010 was the coldest, with average AW/TAW and whole water column temperatures down to $2.1{ }^{\circ} \mathrm{C}$ and $1.6{ }^{\circ} \mathrm{C}$, respectively. The pattern of yearto-year variability in the inner part of Isfjorden is similar to the outer part. During the warmest years (2006-08 and consistently every year since 2013), the average AW/TAW temperature exceeded $2{ }^{\circ} \mathrm{C}$, and salinity was higher than 34.75 . In 2003, 2005 and 2011, the average AW/TAW temperature was about $1.6^{\circ} \mathrm{C}$. During years with overlapping time-series (2011-16), the pattern of AW/TAW temperature variability in Grønfjorden is similar to the outer Isfjorden. The warmest average AW/TAW temperature in Grønfjorden was recorded in $2013\left(5.6^{\circ} \mathrm{C}\right), 2014\left(5.8^{\circ} \mathrm{C}\right)$ and $2016\left(5.4^{\circ} \mathrm{C}\right)$. In Billefjorden, when AW/TAW was present in 2014, its average temperature and salinity were $3.98{ }^{\circ} \mathrm{C}$ and 34.85 , respectively. Even though Billefjorden is not typically directly impacted by AW/TAW (because of sills), observed year-toyear variability of the whole water column characteristics is similar to the one observed in both Isfjorden and Grønfjorden.

We estimated linear trends for both selected domains of Isfjorden (2003-2016) as well as for Billefjorden (2003-2015; Fig. 4). Here, we report only significant trends at $p<0.05$. The outer Isfjorden domain witnessed an increase in the average salinity of the AW/ TAW of $0.012 / y e a r$. The increase in average $S$ and $\mathrm{T}$ in 

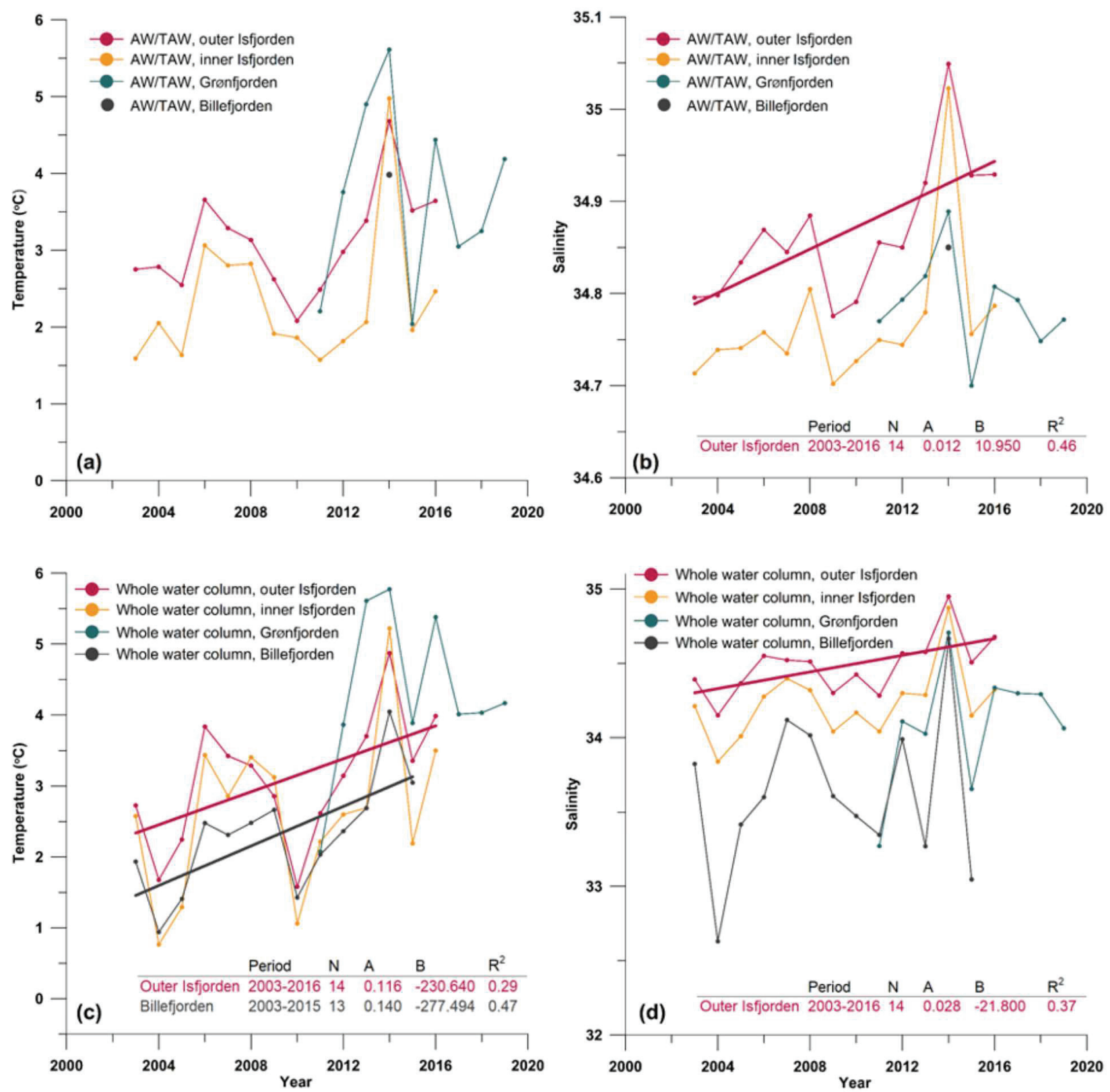

Fig. 4 Interannual variability and linear regression statistics, including regression slope (A), intercept (B) and determination coefficient $\left(R^{2}\right)$ of average temperature and salinity of (a, b) AWITAW and (c, d) the whole water column in Isfjorden and Billefjorden for the period 2003-2016 and in Grønfjorden for the period 2011-19. In 2014, the average AW/TAW temperature (a) and salinity (b) in Billefjorden is shown as a dot. All presented trends are statistically significant at $p<0.05$.

the whole water column of the outer Isfjorden was 1.5-2 times higher compared to AW/TAW layer, 0.028/ year and $0.116^{\circ} \mathrm{C} /$ year, respectively. It is worth noting that the difference in the trend values for $\mathrm{T}$ and $\mathrm{S}$ between the outer and inner parts of Isfjorden is slight. The AW/TAW temperature trend in Billefjorden was $0.140^{\circ} \mathrm{C} /$ year. There may be several possible explanations for the comparable rate of change in $\mathrm{T}$ in Isfjorden and Billefjorden. An increase in temperature can be attributed to not only a change in volume AW/ TAW inflow to fjords but also the long-term (18932013 ) increase in air temperatures of $2.6^{\circ} \mathrm{C}$ in Svalbard (Nordli et al. 2014). Furthermore, according to Isaksen et al. (2016), there has been an air temperature 
increase of $3.4-4.6{ }^{\circ} \mathrm{C}$ in winter and $0.7-1.4^{\circ} \mathrm{C}$ in summer months in 2001-2015 compared to 1971-2000.

\section{Long-term variability of maximum AW/TAW temperature}

Pavlov et al. (2013) revealed strong AW warming patterns in Isfjorden and Grønfjorden at the beginning of the 2000s compared to the previous century (back to 1912). Has this warming signal persisted during the second decade of the 21 st century? We extended the original time series of maximum AW/TAW temperature over the period 1912-2009, as presented by Pavlov et al. (2013), with data collected during the recent decade (Fig. 5). Maximum AW/TAW temperature values after 2010 are in the same temperature range as in the 2000 s.
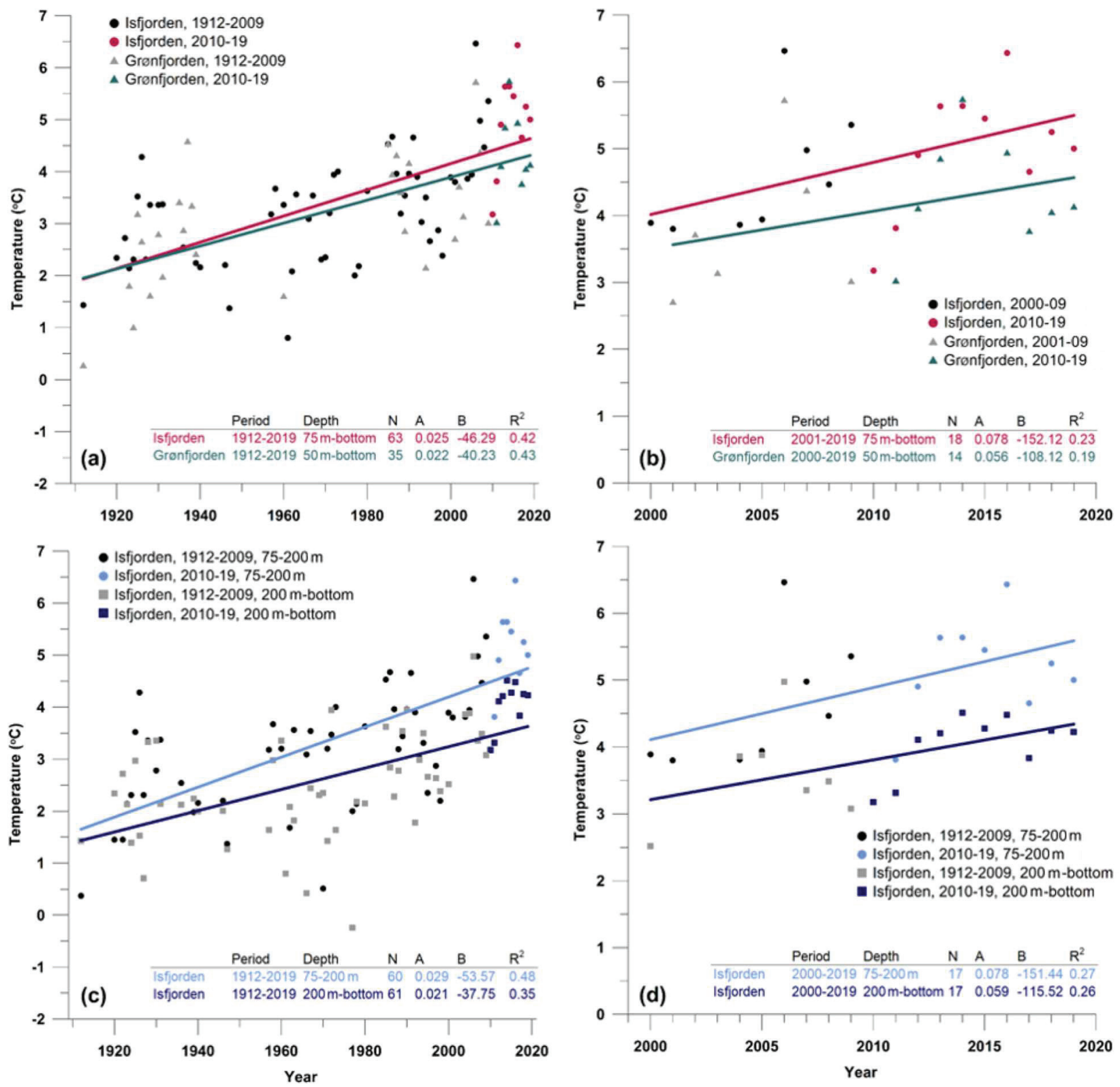

Fig. 5 (a) Time series of maximum AW/TAW temperature for the investigated layers of Isfjorden and Grønfjorden with the best linear-fit trend for the period 1912-2019; (b) same as in (a) but for the period 2000-2019; (c) time series of maximum AW/TAW temperature for two layers of Isfjorden with the best linear fit trend for the period 1912-2019; (d) same as in (c) but for the period 2000-2019. Data for the period 1912-2009 are from Pavlov et al. (2013). All linear trends are statistically significant at $p<0.05$. 
Recorded maxima temperatures of $6.43{ }^{\circ} \mathrm{C}$ in Isfjorden and $5.75^{\circ} \mathrm{C}$ in Grønfjorden in 2016 are very close to maximum AW/TAW temperatures earlier reported in $2006\left(6.46\right.$ and $5.73{ }^{\circ} \mathrm{C}$, respectively; Pavlov et al. 2013).

After adding another decade of observations, the average long-term trend of AW/TAW maximum temperature in Isfjorden increases to $0.25^{\circ} \mathrm{C} /$ decade over the period 1912-2019 compared to $0.19^{\circ} \mathrm{C} /$ decade over the period 1912-2009. The updated trend accounts for $42 \%$ of the variance, compared to only $28 \%$ reported by Pavlov et al. (2013). When we look closely at the time series in the past two decades, the warming trend is more pronounced than earlier: $0.78{ }^{\circ} \mathrm{C} /$ decade in Isfjorden and $0.56{ }^{\circ} \mathrm{C} /$ decade in Grønfjorden through the whole water column. The warming trend in Isfjorden varied by depth and was $0.78^{\circ} \mathrm{C} /$ decade between 75 and $200 \mathrm{~m}$ depth, and $0.59^{\circ} \mathrm{C} /$ decade between $200 \mathrm{~m}$ depth and the bottom (the identical value of $0.078^{\circ} \mathrm{C} /$ year for both depth ranges in Isfjorden is due to the AW/TAW maximum being observed between 75 and $200 \mathrm{~m}$ depth for all years except 2010).

\section{Summary}

We have highlighted the patterns of ongoing 'Atlantification' in Isfjorden, Grønfjorden and Billefjorden in the two first decades of the 21 st century. We found that the warming has been pronounced not only in the outer but also in the inner domain of Isfjorden, with a more frequent presence of AW/TAW after 2011 compared to the early 2000s. Furthermore, there has been an increasing occurrence of AW/TAW in the bottom layers in inner Isfjorden. The year 2014 was the warmest and saltiest for the entire observation period (2003-2019), which is consistent with reports for other west Spitsbergen fjords. The long-term trend of AW/TAW maximum temperature for the period 1912-2019 was $0.25^{\circ} \mathrm{C} /$ decade and $0.22^{\circ} \mathrm{C} /$ decade in the outer part of Isfjorden and Grønfjorden, respectively. In a long perspective, the AW/TAW warming in Isfjorden and Grønfjorden over the past 20 years has been more pronounced compared to the 20th century. The substantial changes in AW/ TAW properties could have important implications for both regional climate and the structure and function of the fjord ecosystem. These findings provide essential knowledge for the research community working across disciplines in Svalbard fjords.

\section{Acknowledgements}

Data in Grønfjorden and Isfjorden were collected during the Spitsbergen-2011-Spitsbergen-2019 expeditions organized by the AARI's RAE-S. The authors express their gratitude to the Department for Coordination and Planning of Scientific Research RAE-S for support and field logistics. The authors thank the staff of the RAE-S in Barentsburg for their assistance in the field research. The authors also thank the two anonymous reviewers whose comments helped to improve the manuscript significantly.

\section{Funding}

This study was conducted as part of AARI's ongoing research activities, under the theme 1.5.4 (НИТР) of the Federal Service for Hydrometeorology and Environmental Monitoring (Roshydromet).

\section{Disclosure statement}

The authors report no conflict of interest.

\section{References}

Aagaard K. \& Carmack E.C. 1989. The role of sea ice and other freshwater in the Arctic circulation. Journal of Geophysical Research-Oceans 94, 14485-14498, doi: 10.1029/JC094i C10p14485.

Årthun M., Eldevik T., Smedsrud L.H., Skagseth Ø. \& Ingvaldsen R.B. 2012. Quantifying the influence of Atlantic heat on Barents Sea ice variability and retreat. Journal of Climate 25, 4736-4743, doi: 10.1175/JCLI-D-11-00466.1.

Asbjørnsen H., Årthun M., Skagseth Ø. \& Eldevik T. 2020. Mechanisms underlying recent Arctic Atlantification. Geophysical Research Letters 47, e2020GL088036, doi: 10. 1029/2020GL088036.

Berge J., Heggland K., Lønne O.J., Cottier F., Hop H., Gabrielsen G.W., Nøttestad L. \& Misund O.A. 2015. First records of Atlantic mackerel (Scomber scombrus) from the Svalbard archipelago, Norway, with possible explanations for the extensions of its distribution. Arctic 68, 54-61, doi: 10.14430/arctic4455.

Berge J., Johnsen G., Nilsen F., Gulliksen B. \& Slagstad D. 2005. Ocean temperature oscillations enable reappearance of blue mussels Mytilus edulis in Svalbard after a 1000 year absence. Marine Ecology Progress Series 303, 167-175, doi: 10.3354/meps303167.

Bischof J. 2000. Ice drift, ocean circulation and climate change. London: Springer.

Boyd T.J. \& D'Asaro E.A. 1994. Cooling of the West Spitsbergen Current: wintertime observations west of Svalbard. Journal of Geophysical Research-Oceans 99, 22597-22618, doi: 10.1029/94JC0182.

Boyer T.P., Baranova O.K., Coleman C., Garcia H.E., Grodsky A., Locarnini R.A., Mishonov M.V., O'Brien T.D., Paver C.R., Reagan J.R., Seidov D., Smolyar I.V., Weathers K. \& Zweng M.M. 2018. World Ocean Database 2018. Accessed on the internet at https://www.ncei. noaa.gov/access/world-ocean-database-select/dbsearch. html on 29 July 2021. 
Cottier F.R., Nilsen F., Inall M.E., Gerland S., Tverberg V. \& Svendsen H. 2007. Wintertime warming of an Arctic shelf in response to large-scale atmospheric circulation. Geophysical Research Letters 34, L10607, doi: 10.1029/2007GL029948.

Cottier F.R., Tverberg V., Inall M.E., Svendsen H., Nilsen F. \& Griffiths C. 2005. Water mass modification in an Arctic fjord through cross-shelf exchange. Journal of Geophysical Research-Oceans 110, el2005, doi: 10.1029/2004JC002757.

Goszczko I., Ingvaldsen R.B. \& Onarheim I.H. 2018. Winddriven cross-shelf exchange-West Spitsbergen Current as a source of heat and salt for the adjacent shelf in Arctic winters. Journal of Geophysical Research-Oceans 123, 2668-2696, doi: 10.1002/2017JC013553.

Haarpaintner J., Gascard J.-C. \& Haugan P.M. 2001. Ice production and brine formation in Storfjorden, Svalbard. Journal of Geophysical Research-Oceans 106, 14001-14013, doi: 10.1029/1999JC000133

Helland-Hansen B. \& Nansen F. 1912. The sea west of Spitsbergen: the oceanographic observations of the Isachsen Spitsbergen Expedition in 1910. Videnskaps-selskapets Skrifter I. Mathematisk-naturvidenskapelig Klasse 12. Christiania (Oslo): Norwegian Academy of Science and Letters (Videnskapsselskapet i Kristiania).

Holmes F.A., Kirchner N., Kuttenkeuler J., Krützfeldt J. \& Noormets R. 2019. Relating ocean temperatures to frontal ablation rates at Svalbard tidewater glaciers: insights from glacier proximal datasets. Science Reports 9, article no. 9442, doi: 10.1038/s41598-019-45077-3.

Hop H., Wold A., Vihtakari M., Daase M., Kwasniewski S., Gluchowska M., Lischka S., Buchholz F. \& Falk-Petersen S. 2019. Zooplankton in Kongsfjorden (1996-2016) in relation to climate change. In H. Hop \& C. Wiencke (eds.): The ecosystem of Kongsfjorden, Svalbard. Pp. 229-300. Cham: Springer.

Isaksen K., Nordli Ø., Førland E.J., Łupikasza E., Eastwood S. \& Niedźwiedź T. 2016. Recent warming on Spitsbergen-influence of atmospheric circulation and sea ice cover. Journal of Geophysical Research-Atmospheres 121, 11913-11931, doi: 10.1002/2016JD025606.

Kolås E. \& Fer I. 2018. Hydrography, transport and mixing of the West Spitsbergen Current: the Svalbard Branch in summer 2015. Ocean Science 14, 1603-1618, doi: 10.5194/ os-14-1603-2018.

Łącka M. \& Zajączkowski M. 2016. Does the recent pool of benthic foraminiferal tests in fjordic surface sediments reflect interannual environmental changes? The resolution limit of the foraminiferal record. Annales Societatis Geologorum Poloniae 86, 59-71, doi: 10.14241/ asgp.2015.019.

Luckman A., Benn D.I., Cottier F., Bevan S., Nilsen F. \& Inall M. 2015. Calving rates at tidewater glaciers vary strongly with ocean temperature. Nature Communications 6, article no. 8566 , doi: $10.1038 /$ ncomms 9566 .

Mańko M.K., Gluchowska M. \& Weydmann-Zwolicka A. 2020. Footprints of Atlantification in the vertical distribution and diversity of gelatinous zooplankton in the Fram Strait (Arctic Ocean). Progress in Oceanography 189, article no. 102414, doi: 10.1016/j.pocean.2020.102414.
Nansen F. 1915. Spitsbergen waters, oceanographic observations during the cruise of the Eslemøy to Spitsbergen in 1912. Videnskapsselskapets Skrifter I. Mathematisk-naturvidenskapelig Klasse 2. Christiania (Oslo): Norwegian Academy of Science and Letters (Videnskapsselskapet i Kristiania).

Nilsen F., Cottier F., Skogseth R. \& Mattsson S. 2008. Fjordshelf exchange controlled by ice and brine production: the interannual variation of Atlantic Water in Isfjorden, Svalbard. Continental Shelf Research 28, 1838-1853, doi: 10.1016/j.csr.2008.04.015.

Nilsen F., Skogseth R., Vaardal-Lunde J. \& Inall M.E. 2016. A simple shelf circulation model: intrusion of Atlantic Water on the West Spitsbergen Shelf. Journal of Physical Oceanography 46, 1209-1230, doi: 10.1175/ JPO-D-15-0058.1.

Nordli Ø., Przybylak R., Ogilvie A. \& Isaksen K. 2014. Long-term temperature trends and variability on Spitsbergen: the extended Svalbard Airport temperature series. Polar Research 33, 1898-2012, doi: 10.3402/ polar.v33.21349.

Pavlov A.K., Tverberg V., Ivanov B.V., Nilsen F., Falk-Petersen S. \& Granskog M.A. 2013. Warming of Atlantic Water in two Spitsbergen fjords over the last century (1912-2009). Polar Research 32, article no. 11206, doi: 10.3402/polar. v32i0.11206.

Payne C.M. \& Roesler C.S. 2019. Characterizing the influence of Atlantic water intrusion on water mass formation and phytoplankton distribution in Kongsfjorden, Svalbard. Continental Shelf Research 191, article no. 104005, doi: 10.1016/j.csr.2019.104005.

Polyakov I.V., Alkire M.B., Bluhm B.A., Brown K.A., Carmack E.C., Chierici M., Danielson S.L., Ellingsen I., Ershova E.A., Gårdfeldt Katarina, Ingvaldsen R.B., Pnyushkov A.V., Slagstad D. \& Wassmann P. 2020. Borealization of the Arctic Ocean in response to anomalous advection from sub-Arctic seas. Frontiers in Marine Science 7, article no. 491, doi: 10.3389/fmars.2020.00491.

Polyakov I.V., Pnyushkov A.V., Alkire M.B., Ashik I.M., Baumann T.M., Carmack E.C. \& Yulin A. 2017. Greater role for Atlantic inflows on sea-ice loss in the Eurasian Basin of the Arctic. Ocean. Science 356, 285-291, doi: 10.1126/ science.aai8204.

Promińska A., Cizek M. \& Walczowski W. 2017. Kongsfjorden and Hornsund hydrography—comparative study based on a multiyear survey in fjords of west Spitsbergen. Oceanologia 59, 397-412, doi: 10.1016/j.oceano.2017.07.003.

Rudels B., Korhonen M., Schauer U., Pisarev S., Rabe B. \& Wisotzki A. 2015. Circulation and transformation of Atlantic water in the Eurasian Basin and the contribution of the Fram Strait inflow branch to the Arctic Ocean heat budget. Progress in Oceanography 132, 128-152, doi: $10.1016 /$ j.pocean.2014.04.003.

Saloranta T.M. \& Svendsen H. 2001. Across the Arctic Front west of Spitsbergen: high-resolution CTD sections from 19982000. Polar Research 20, article no. 177184, doi: 10.3402/polar.v20i2.6515.

Schauer U., Beszczynska-Moller A., Walczowski W., FahrbachE., Piechura J. \& Hansen E. 2008. Variation of measured heat flow through the Fram Strait Between 
1997 and 2006. In R.R. Dickson et al. (eds.): Arctic Subarctic ocean fluxes: defining the role of the northern seas in climate. Pp. 65-85. Dordrecht: Springer.

Skogseth R., Olivier L.L.A., Nilsen F., Falck E., Fraser N., Tverberg V., Ledang A.B., Vader A., Jonassen M.O., Søreide J., Cottier F., Berge J., Ivanov B.V. \& Falk-Petersen S. 2020. Variability and decadal trends in the Isfjorden (Svalbard) ocean climate and circulation-an indicator for climate change in the European Arctic. Progress in Oceanography 187, article no. 102394, doi: 10.1016/j.pocean.2020.102394.

Svendsen H., Beszczynska-Møller A., Hagen J.O., Lefauconnier B., Tverberg V., Gerland S., Ørbek J.B., Bischof K., Pappucci C., Zajaczkowski M., Azzolini R., Bruland O., Wiencke C., Winther J.-G. \& Dallmann W. 2002. The physical environment of Kongsfjorden-Krossfjorden, an
Arctic fjord system in Svalbard. Polar Research 21, 133-166, doi: $10.1111 /$ j. 1751

Tverberg V., Skogseth R., Cottier F., Sundfjord A., Walczowski W., Inall M.E., Falck E., Pavlova O. \& Nilsen F. 2019. The Kongsfjorden transect: seasonal and inter-annual variability in hydrography. In H. Hop \& C. Wiencke (eds.): The ecosystem of Kongsfjorden, Svalbard. Pp. 49-104. Cham: Springer.

Vihtakari M., Welcker J., Moe B., Chastel O., Tartu S., Hop H., Bech C., Descamps S. \& Wing Gabrielsen G. 2018. Blacklegged kittiwakes as messengers of Atlantification in the Arctic. Scientific Reports 8, article no. 1178, doi: 10.1038/ s41598-017-19118-8.

Zhuravskiy D., Ivanov B. \& Pavlov A. 2012. Ice conditions at Gronfjorden Bay, Svalbard, from 1974 to 2008. Polar Geography 35, 169-176, doi: 10.1080/1088937X.2012.662535. 